\title{
Somogyi Agota
}

Közgazdasági Politechnikum Alternatív Gimnázium és Szakközépiskola, Budapest

\section{A SAILS projekt tapasztalatai a pedagógus szemszögéből:}

\section{a kutatásalapú tanulás szervezésének és értékelésének hatása a pedagógus attitüdjére}

A kutatásalapú tanulással elöször a PRIMAS projekt keretében (Csíkos, 2010) foglalkoztam intenzívebben és tudatosabban. Ebben az idószakban ismerkedtem meg az alapelvekkel és a módszerekkel. A SAILS projektben (Csapó, Csíkos és Korom, 2016) már a kezdetektól részt vettem, így vált számomra a kutatási készségek fejlesztése az értékeléssel együtt teljessé. A SAILS projekt

keretében két tanulási egységet (unitot) - A szabadon esó tojás ütközésének vizsgálata különbözố minốségú talajok esetén és a Talaj humusz és nedvességtartalmának meghatározása - fejlesztettem, valamint a tanítványaimmal együtt kipróbáltam a külföldi partnerek

tanulási egységei közül kettốt (Floating orange és Black tide oil). A tojások ütközését vizsgáló feladatomat (Collision of an egg) több külföldi partner is kipróbálta, az eredményekról esettanulmányok készültek (Finlayson, McLoughlin, Coyle, McCabe, Lovatt és van Kampen, 2015).

\begin{abstract}
A SAILS hazai tanárképzésében és tanártovábbképzésében oktatóként segítettem a tanárjelölteknek, kollégáknak megismerkedni azokkal a módszerekkel, melyeket a gyakorlatban alkalmazva szervezhetővé, követhetővé és értékelhetővé válnak a kutatásalapú feladatok még akkor is, ha a foglalkozáson előkerülő probléma strukturálatlan. A tanulmány első részében bemutatom, hogy a projekt hogyan változtatta meg a tanításról alkotott elképzeléseimet, majd a második részben A szabadon eső tojás ütközése tanulási egységen keresztül tekintem át az értékelési stratégia változását a saját tapasztalataim és a partnerek esettanulmányainak függvényében.
\end{abstract}

\section{Hogyan valósult meg a SAILS célja?}

A projekt végén, a tapasztalataim összegzésekor átgondoltam, mi volt a projekt célja, és hogyan valósult meg számomra.

„A SAILS célja azon túl, hogy a tanárok képesek legyenek a természettudományok tanítása során a kutatásalapú tanítás módszereit alkalmazni, felkészültek legyenek diákjaik értékelésére is a kutatásalapú tanítás, tanulás során. A SAILS célja, hogy 
segítse a tanárokat értékelési stratégiáik, módszereik fejlesztésében, és támogassa őket azoknak a fontos kutatási készségeknek az értékelésében, amelyeket nehéz megragadni a hagyományos vizsgáztatás feltételei mellett."

Az önértékelés során arra a következtetésre jutottam, hogy ezeket a célokat akkor lehet megvalósítani, ha változik a tanár attitüdje, szemléletmódja, és fejlődnek a megvalósításhoz szükséges készségei is. A saját tanítási gyakorlatomban módszereket, eszközöket kerestem a napi iskolai tevékenységek sikerének növelése érdekében. Az a cél lebegett a szemem előtt, hogy diákjaim izgalmas, mindenki számára sikeres foglalkozások során sajátítsák el a tananyagot. A módszertani fejlődésre irányuló törekvéseim akkor vezettek eredményre, amikor a szemléletem több szempontból is megváltozott, és tudatosultak számomra a következők:

- A tananyag kulcsfogalmainak megismerése, alkalmazása, szintézise nem csak a saját elképzeléseim szerint történhet, a diákoknak célszerü nagyobb teret hagyni.

- A diákok kutatási készségeinek fejlesztése felöl is megközelíthető a természettudományos tananyag kulcsfogalmainak megértése, alkalmazása.

- A pedagógus feladata az, hogy megteremtse azokat a körülményeket, kereteket, melyek lehetővé teszik a diák számára a saját szintjén történő kutatást, tanulást.

- A diák és a szülő számára fontos, hogy tudja, mi miért történik az órákon, foglalkozásokon.

- Az értékelés szerves része a kutatási készségek fejlesztésének.

A szemléletváltást követően a tanári készségeimnek, képességeimnek is fejlödniük kellett. Az első kutatásalapú foglalkozások elemzése során szembesültem azzal, hogy mennyire vagyok nyitott és fogékony az új és eltérő nézőpontok iránt. Számos kérdést igyekeztem magam számára elemezni, megválaszolni: Hogyan tudok különböző néző-

A szemléletváltást követốn a tanári készségeimnek, képességeimnek is fejlödniük kellett. Az elsó kutatásalapú foglalkozások elemzése során szembesültem azzal, hogy mennyire vagyok nyitott és fogékony az új és eltérố nézópontok iránt. Számos kérdést igyekeztem magam számára elemezni, megválaszolni: Hogyan tudok különbözó nézópontokat tisztázó, jobb megoldáshoz vezetó lényegi kérdéseket feltenni? Hogyan tudom az információkat rendszerezni, elemezni és összegezni a problémamegoldás és a válaszok megtalálása érdekében? Mennyire vagyok rugalmas és kompromisszumkész? Milyen szintú a kommunikációm, lényegkiemelésem? Hogyan tudok alkalmazkodni a különbözó szerepekhez? pontokat tisztázó, jobb megoldáshoz vezetỏ lényegi kérdéseket feltenni? Hogyan tudom az információkat rendszerezni, elemezni és összegezni a problémamegoldás és a válaszok megtalálása érdekében? Mennyire vagyok rugalmas és kompromisszumkész? Milyen szintủ a kommunikációm, lényegkiemelésem? Hogyan tudok alkalmazkodni a különböző szerepekhez?

Tapasztalataim alapján bármely életkorban fejleszthetőek a kutatásalapú tanulás facilitálásához szükséges tanári készségek, de fel kell készülni arra, hogy a kereteket, az értékelés formáját, eszközeit a saját készségszintünknek megfelelően válasszuk meg, különben kudarcnak éljük meg a kutatásalapú módszerek használatát. A kutatásalapú 
tanítást segítő keretrendszer akkor jó, ha több szinten, sokféle eszközt ad a tanárok kezébe, s megadja annak a lehetőségét, hogy a tanár maga válassza ki a számára megfelelö eszközöket. A SAILS projekt során sokféle tanár sokféle eszközt hozott létre a megadott keretrendszerben.

\section{Mely kutatási készségeket, hogyan lehet értékelni a kutatásalapú tanulás során?}

A kutatásalapú tanulás alkalmazásakor fokozatosan tértem át a strukturált feladatokról a nyílt végü, strukturálatlan feladatokra. A szabadon eső tojás ütközésének vizsgálata kutatási feladat (1. ábra) célja eredetileg az volt, hogy a diákok a megadott eszközök segítségével tervezzenek kísérletet annak vizsgálatára, hogy milyen tényezők befolyásolják a testre ható erőt az ütközés során. A feladat akkor alkalmazható, amikor a diákok már tanultak a szabadesésröl, ismerik a lendület, az erő fogalmát, a lendületváltozás és az erő közötti összefüggést.

A kutatási készségek jobb megfigyelése érdekében több lépésre bontottam a feladat végrehajtását. Az első lépésben a változók felismerése, azonosítása került a középpontba. A diákok négyfös csoportokban gyüjtötték össze azokat a tényezőket, amelyek befolyásolják az ütközés során a tojásra ható erőket. Ezt követően kísérletet terveztek az ütközés során a tojásra ható erő vizsgálatára. Ebben a fázisban azt figyeltem meg, hogy a csoportok hogyan kezelik a változókat, hogyan ismerik fel a változók közötti összefüggéseket. A harmadik lépésben a diákok kis csoportokban végrehajtották a kísérleteket és rögzítették a tapasztalatokat. Arra törekedtem, hogy megfigyeljem a kísérlet kivitelezését, a változók kezelését és a tapasztalatok rögzítését. Az eredeti feladat negyedik lépésében a csoportok kísérletet terveztek arra, hogy az iskola második emeleti folyosójáról hogyan lehet egy tojást sértetlenül ledobni az alagsorba $15 \mathrm{~m}$ magasságból. Arra gondoltam, hogy a megfigyeléseiket felhasználva tervezik meg a kísérletet. A későbbiekben átalakítottam a feladatot, mert a változókat nem akartam azzal is bővíteni, hogy a diákok a tojás köré különböző anyagokat rakjanak. A SAILS projektben használt, a partnerek által kipróbált tanulási egység feladatlapját már úgy alakítottam ki, hogy a kutató kérdésben az egyik változó a magasság legyen.

A tanulási egység tervezése és megvalósítása során az értékelő táblázat (rubrikák) lehetőséget ad arra, hogy a lehető legtöbb kutatási készség megfigyelhetővé és értékelhetővé váljon a foglalkozások során. A külföldi kollégák javaslatait figyelembe véve dolgoztam ki egy háromszintű rendszert minden, a foglalkozás során fejleszteni és értékelni kívánt kutatási készségre (1. táblázat). 


\section{MILYEN TÉNYEZŐK BEFOLYÁSOLJÁK AZ ÜTKÖZÉS SORÁN A TESTRE HATÓ ERŐT?}

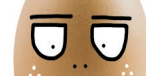

A mintrinhapi életünkben fontos a biztonságos közlekedés. A különbözö jármüvekkel történö utazás során az ember testi épségének védelme elsödleges a közlekedésbiztonságban.

A védelmet biztositó eszközök kifejlesztéséhez ismerni kell az ütközés során a testre ható eröt befolyásoló tényezöket.

Az ütközés során fellépő kölcsönhatás tanulmányozásához a szabadon eső tojás földet érésének a vizsgálatát javasoljuk.

\section{Milyen tényezők és hogyan befolyásolják a tojás biztonságos földet érését?}

1. Gyüjtsd össze társaid segítségével azokat a tényezőket, amelyek befolyásolják az ütközéskor a tojásra ható eröt!

2. Tervezzetek 3-4 fös csoportokban kísérletet a különböző tényezők vizsgálatára! A vizsgálathoz rendelkezésre álló eszközök, anyagok: tálca, rongy, vödör, mélyebb tál, mérőszalag, vonalzó, stopper, egy doboz tojás, digitális mérleg, víz, gríz, liszt, kavicsos homok, lufi.

Egyeztess a tanároddal, ha a kísérlet során szükséged lenne egyéb eszközre, anyagra!

A tervezés során ne felejtsd el a különböző változókat azonosítani: a független változót (amelyik változik), a függö változót (amelyiket megfigyelsz, vagy mérsz) és az állandónak választott változót (amelyiket a megfigyelés során állandónak választasz).

2.1. Mielőtt a csoport nekifog a kísérletezésnek, egyeztessen a tanárral!

2.2. Készítsetek tervet a kivitelezéshez és írásban rögzítsétek a várt eredményeket!

2.3. Hajtsátok végre a kísérletet és rögzítsétek a mért adatokat és a megfigyelést!

\section{Milyen magasról lehet egy vödör lisztbe leejteni egy tojást, hogy ne törjön össze?}

3.1. Az előző kísérleti tapasztalataitok alapján becsüljétek meg, hogy milyen magasról lehet törés nélkül egy tojást leejteni egy vödör lisztbe!

3.2. Hasonlítsátok össze a csoportok feltevéseit! Válasszátok ki azt, amelyik szerintetek a legvalószínübb!

3.3. Végezzétek el a kísérletet!

4. Beszéljétek meg a csoportban, hogy milyen kapcsolat van a vizsgálati tapasztalatok és a közlekedésbiztonsági eszközök, berendezések között! 
Somogyi Ágota: A SAILS projekt tapasztalatai a pedagógus szemszögéböl:

1. táblázat. Értékelö táblázat (rubrikák) a szabadon esö tojás ütközésének vizsgálata tanulási egységhez

\begin{tabular}{|c|c|c|c|}
\hline Kutatási készség & 1. szint & 2. szint & 3. szint \\
\hline Kérdésfelvetés & $\begin{array}{l}\text { A tanuló nem ismeri fel a } \\
\text { kérdés és a kísérlet közötti } \\
\text { kapcsolatot, nem segíti a } \\
\text { munkáját a kérdés. }\end{array}$ & $\begin{array}{l}\text { A tanuló felismeri a kérdés } \\
\text { és a kísérlet közötti kap- } \\
\text { csolatot, de nem segíti a } \\
\text { munkáját a kérdés. }\end{array}$ & $\begin{array}{l}\text { A tanuló felismeri a kér- } \\
\text { dés és a kísérlet közötti } \\
\text { kapcsolatot, a munkájába } \\
\text { szisztematikusan beépíti a } \\
\text { válaszokat. }\end{array}$ \\
\hline Hipotézisalkotás & $\begin{array}{l}\text { A tanuló megfogalmazza } \\
\text { a feltevését, de nem képes } \\
\text { magyarázatot adni a hipo- } \\
\text { tézisére. }\end{array}$ & $\begin{array}{l}\text { A tanuló megfogalmazza } \\
\text { a feltevését, s képes segít- } \\
\text { séggel magyarázatot adni } \\
\text { rá. }\end{array}$ & $\begin{array}{l}\text { A tanuló megfogalmazza } \\
\text { a hipotézisét, s tudomá- } \\
\text { nyos magyarázattal alá is } \\
\text { támasztja azt. }\end{array}$ \\
\hline Kísérlet tervezése & $\begin{array}{l}\text { A tanuló javaslatot tesz a } \\
\text { jelenség vizsgálatára, de } \\
\text { nem látja részleteiben azt. }\end{array}$ & $\begin{array}{l}\text { A tanuló javaslatot tesz a } \\
\text { jelenség vizsgálatára, rész- } \\
\text { leteiben is látja a folyama- } \\
\text { tot, de önállóan nem képes } \\
\text { annak átgondolására. }\end{array}$ & $\begin{array}{l}\text { A tanuló képes megtervez- } \\
\text { ni a kísérletet, a tervezés } \\
\text { során képes azonosítani a } \\
\text { függó és a független vál- } \\
\text { tozókat. Felismeri az ösz- } \\
\text { szefüggéseket a változók } \\
\text { között. Azonosítani tudja a } \\
\text { törvényszerüségeket. }\end{array}$ \\
\hline Kísérlet kivitelezése & $\begin{array}{l}\text { A tanuló tanári irányítás- } \\
\text { sal, konzultációval képes } \\
\text { a vizsgálat kivitelezésére. } \\
\text { A megfigyeléseit szórvá- } \\
\text { nyosan leírja, felvázolja. }\end{array}$ & $\begin{array}{l}\text { A tanuló képes a vizsgálat } \\
\text { kivitelezésére, időnként } \\
\text { segítségre szorul. Megfi- } \\
\text { gyeléseit írásban, ábrával } \\
\text { rögzíti, a dokumentációja } \\
\text { hiányos, helyenként pon- } \\
\text { tatlan. }\end{array}$ & $\begin{array}{l}\text { A tanuló önállóan vagy } \\
\text { csoportban képes a vizsgá- } \\
\text { lat kivitelezésére. A megfi- } \\
\text { gyeléseit pontosan rögzíti } \\
\text { írásban, rajzos ábrákkal. } \\
\text { A dokumentációja pontos. }\end{array}$ \\
\hline $\begin{array}{l}\text { Következtetések a } \\
\text { vizsgálati eredmé- } \\
\text { nyekből }\end{array}$ & $\begin{array}{l}\text { A tanuló képes a vizsgálat } \\
\text { bemutatására, következ- } \\
\text { tetések megállapítására. } \\
\text { A következtetés során a } \\
\text { vizsgálati eredményböl } \\
\text { csak keveset használ. } \\
\text { A hipotézis és a vizsgálat } \\
\text { eredményét képes össze- } \\
\text { hasonlítani. }\end{array}$ & $\begin{array}{l}\text { A tanuló következtetései a } \\
\text { vizsgálati eredményeken } \\
\text { alapulnak. A hipotézist és } \\
\text { a vizsgálat eredményét ké- } \\
\text { pes összehasonlítani. }\end{array}$ & $\begin{array}{l}\text { A tanuló következtetései a } \\
\text { vizsgálati eredményeken } \\
\text { alapulnak. A hipotézist és } \\
\text { a vizsgálat eredményét } \\
\text { képes összehasonlítani. } \\
\text { A vizsgálati eredmények } \\
\text { okát képes feltárni. }\end{array}$ \\
\hline A kísérlet értékelése & $\begin{array}{l}\text { A tanuló felismeri a le- } \\
\text { hetséges hibaforrásokat. } \\
\text { Képes az eredményeinek } \\
\text { valóságtartalmát megvizs- } \\
\text { gálni. }\end{array}$ & $\begin{array}{l}\text { A tanuló felismeri a le- } \\
\text { hetséges hibaforrásokat. } \\
\text { Képes az eredményeinek } \\
\text { valóságtartalmát megvizs- } \\
\text { gálni. Beazonosítja a hibát. }\end{array}$ & $\begin{array}{l}\text { A tanuló képes az eredmé- } \\
\text { nyeinek valóságtartalmát } \\
\text { megvizsgálni, összehason- } \\
\text { lítani más eredményekkel. } \\
\text { Felismeri a hibaforrásokat, } \\
\text { s azok hatását a vizsgálati } \\
\text { eredményekre. }\end{array}$ \\
\hline
\end{tabular}

A tanulási egység tanórai kipróbálása során a csoportok munkájának szervezése, a segítő kérdések megfogalmazása elvonta a figyelmemet az értékelő táblázatról. A foglalkozás után átnézve az órai dokumentációt és a diákok munkáját arra a következtetésre jutottam, hogy az általam kidolgozott háromszintü értékelési skála nagyon általános, és túl sok készséget szeretne egyszerre értékelni. Elönye viszont, hogy keretet ad az értékeléshez, a foglalkozás után segíti egy-egy csoport, diák munkájának értékelő összegzését. Bár a táblázat egyéni munka értékelésére készült, a diákok csoportban dolgoztak, s így inkább a csoportok tagjainak együttes formatív értékelésére alkalmaztam.

A foglalkozás során a diákok készségszintjét a segítő kérdéseim és az írásbeli munkáik alapján próbáltam azonosítani. Tapasztalataimat esettanulmányban rögzítettem, melynek 
egy részlete a 2. ábrán látható. Az értékelés fejlesztésében segítségemre volt, hogy felvétel készült az óráról. Fontos tapasztalat volt számomra, hogy az órán nem lehet egyszerre minden szempont szerint értékelni a diákokat. Érdemes kiválasztani az értékelési terv elkészítése során azt a két-három szempontot, amelyre a formatív értékelés koncentrál.

A diákok hipotézisalkotása föleg a $15 \mathrm{~m}$ magasból leejtett tojás épségben maradására vonatkozott. A hat csoportból két csoport használta fel az előzetes megfigyelés eredményét. A változók azonosítása, a független és a függő változók kiválasztása az előismeretek alapján minden csoportban megtörtént (2. ábra).

\section{Megfigyelés:}

\section{1. csoport}

Tanár: „Hogyan tudod állandónak tartani a tojás sebességét?”

Diák: „Mindig ugyanonnan ejtem le.”

A csoport bemutatja a tervet:

„Megnézzük, hogy különböző anyagokra hogyan reagál a tojás, és azonos magasságból fogjuk dobni."

Következtetés: A diákok deduktív gondolkodással a már meglévő információból összegeztek. A változók azonosításával kiválasztották a függő és a független változókat, s alkalmazták a szabályfelismerést.

Második lépésben kis csoportban terveztek a tanulók egy kísérletet, melynek segítségével megvizsgálták az ütközés során a tojásra ható erőt.

Kutatási készségek: változók kezelése, összefüggések felismerése, hipotézis alkotása

Segítő kérdések: Melyik változó tartható állandónak a megfigyelés során? Hogyan lehet összefüggést megállapítani a változók között? Hogyan lehet változtatni egy test lendületét? Mitöl függ a földet érés sebessége? Hogyan befolyásolja az ütközést a tojás ejtési magassága? Milyen változót lehet a talaj minőségével változtatni?

\section{Megfigyelés:}

\section{4. csoport}

Diák bemutatja a tervet a tanárnak:

„A tojást $50 \mathrm{~cm}$-ről, 1 m-ről és 2 m-ről ejtjük le. A kérdések segítségével megvizsgáljuk, hogy milyen összefüggések vannak a különböző magasságok közt, illetve hogy milyen anyagra ejtjük. Felírtuk, hogy milyen erők hatnak a tojásra: gravitáció, súlyerö, légellenállás és a talaj által kifejtett ellenerő."

Következtetés, értékelés: A diákok felismerték a változók közötti kapcsolatot, kiválasztották a függő és a független változókat. A magasságok megállapításánál nem rendelkeztek hipotézissel, nem tudták indokolni a magassági adatokat. A kísérlet tervezése során a tanult szabályszerüség felismerésére és összefüggések megállapítására törekedtek. 
Fakultációs foglalkozás keretében a fizika iránt komolyabban érdeklődő diákokkal is kipróbáltam ezt a feladatot. A megfigyelést mérésekkel és számításokkal egészítettük ki, megbecsültük az ütközés során a tojásra ható erőt. Több problémával is szembesültünk, például azzal, hogy az ütközés idejének a mérése egyszerü eszközökkel nem kivitelezhető. A diákok a GoPro kamera használatát javasolták, mert arról is szerettek volna meggyőződni, hogy a 15 m-ről a vízbe érkező tojás a víz felszínén vagy a vödör alján törik-e össze. Nem sikerült pontos méréseket végezni még a kamera segítségével sem, de arról meggyőződhettek, hogy a tojás a vízbe éréskor törik össze. A diákok szembesültek azzal, hogy miért fontos a mérési hibák azonosítása, a mérési hibahatár beépítése a kutatásba, s mire használható a GoPro kamera. Ennél a csoportnál már nem tudtam alkalmazni az eredeti értékelőlapot, a 3. szintet kellett volna finomítani.

\section{Hogyan alakitható át az értékelés a partnerek és a saját tapasztalataim alapján?}

A partnerek közül egy dán kolléga 13 éves diákokkal, két angol kolléga 12-13 és 11-12 éves diákokkal próbálta ki a tanulási egységet. Esettanulmányaikból kiderül, hogy különböző módokon szervezték meg a diákok munkáját, egyedül a dán kolléga követte pontosan az eredeti tanulási egység útmutatásait. Két tanulócsoportnak nem volt kutatási tapasztalata, míg egy csoport gyakorlottabbnak bizonyult. A javaslatnak megfelelően három kutatási készség értékelésére fordítottak figyelmet a kollégák. A kísérlettervezés, a hipotézisalkotás és az együttműködés a csoportban kutatási készségek kerültek fókuszba. Az egyik angol csoport önértékeléshez használta az értékelő sablont.

A háromfokozatú skála nem bizonyult elegendőnek, az egyes tanulócsoportok más-más szintű megfogalmazást igényeltek. A külföldi kollégák és a saját tapasztalataim is megerősítettek abban, hogy az értékelő rubrikák átalakítása az adott tanulócsoportra, az értékelési célok szükítése, a kitöltött tanulói feladatlapok, kutatási naplók részletes elemzése árnyaltabb, objektívebb értékelést biztosít.

A hipotézisalkotás értékeléséhez elegendő az a feladat, amely azt vizsgálja, hogy azonos magasságból három különböző anyaggal - például nedves homok, víz és liszt - megtöltött vödörbe ejtve mi történik a tojással. A hipotézisalkotás készségéhez tartozó szintek függnek a korosztálytól, a kutatásalapú tanulásbeli jártasságtól. Az általam tanított 12-13 éves diákok számára átalakított értékelő lapot a 2. táblázat mutatja be.

2. táblázat. A hipotézisalkotás értékelö lapja

\begin{tabular}{|c|c|c|c|c|}
\hline Segitö kérdések & 1. szint & 2. szint & 3. szint & 4. szint \\
\hline $\begin{array}{l}\text { Mit gondolsz, mi fog } \\
\text { történni? } \\
\text { Miért következik be } \\
\text { a jelenség? } \\
\text { A tanultak alapján } \\
\text { meg tudod } \\
\text { magyarázni a } \\
\text { hipotézised? }\end{array}$ & $\begin{array}{l}\text { A tanuló } \\
\text { bizonytalan a } \\
\text { feltevése megfogal- } \\
\text { mazásában. }\end{array}$ & $\begin{array}{l}\text { A tanuló } \\
\text { megfogalmazza a } \\
\text { feltevését, de még } \\
\text { a saját tapasztalatai } \\
\text { alapján sem képes } \\
\text { indokolni azt. }\end{array}$ & $\begin{array}{l}\text { A tanuló } \\
\text { megfogalmazza } \\
\text { a hipotézisét, s } \\
\text { segítséggel képes } \\
\text { indokolni azt a } \\
\text { saját tapasztalatai } \\
\text { alapján. }\end{array}$ & $\begin{array}{l}\text { A tanuló } \\
\text { megfogalmazza } \\
\text { a hipotézisét, } \\
\text { s tudományos } \\
\text { magyarázattal alá } \\
\text { is támasztja azt. }\end{array}$ \\
\hline
\end{tabular}

Az értékelési célok megfogalmazása, a diákok írásbeli munkájának adott szempont szerinti értékelése nemcsak a tanár szempontjai szerint müködött, hanem a diákok önértékelését is lehetővé tette, s ez sikerélményt adott a diákoknak is. Az egyik angol kolléga által felvetett, a tojásejtéssel kapcsolatos etikai probléma miatt sokkal megfontoltabban és ritkábban alkalmazom ezt a kutatási feladatot. 


\section{Hogyan alkalmazom a kutatásalapú tanulást és annak értékelését a tanitási gyakorlatomban?}

A megváltozott tanítási attitüd, a diákok sikerélménye és érdeklődése arra ösztönöz, hogy a kutatásalapú tanulás minél több kulcsfogalom körbejárásánál alapvető eszköz legyen. A tanítási gyakorlatomban törekszem arra, hogy minél többször legyen alkalmuk a diákoknak hipotézist alkotni, kérdéseket feltenni az adott témával kapcsolatban.

A témahetek és a projektek kialakításánál a kutatási készségek fejlesztése kerül előtérbe. Egy nemzetközi projekt - Erasmus Gardening: Culture and science - keretében hét ország tanáraival és diákjaival együttmüködve alkalmazzuk a kutatásalapú tanulást a különböző iskolai kertekben elültetett, azonos fajtájú magról fejlődő növények tanulmányozásához.

A formatív és a diagnosztikus értékelést is sokkal tudatosabban, értékelési terv készítésével alakítom ki, a tanulók előzetesen felmért szintjének megfelelően. A tanórán a diák és a készségfejlesztés kerül a középpontba, s a tananyag adja ehhez a keretet. Értékelési tapasztalataimat az iskolánk pedagógiai programjában szereplö, évente kétszer írandó szöveges értékelések fejlesztésébe is beépítem.

\section{Irodalomjegyzék}

Csapó Benő, Csíkos Csaba és Korom Erzsébet (2016): Értékelés a kutatásalapú természettudománytanulásban - a SAILS projekt. Iskolakultúra, 26. 3. sz.3-16.
Csíkos Csaba (2010): A PRIMAS projekt. Iskolakultúra, 20. 12. sz. 4-12.

Finlayson, O., McLoughlin, E., Coyle, E., McCabe, D., Lovatt, J. és van Kampen, P. (2015, szerk.): SAILS inquiry and assessment units. Volume 2. 33-45. 